\title{
Molecular Cloning and Characterization of Auxin- regulated Genes from Mungbean Hypocotyls during Adventitious Root Formation
}

\author{
Jun Chen, Dengru Wu, Francis H. Witham, Charles W. Heuser, and Richard N. Arteca ${ }^{1}$ \\ Department of Horticulture, The Pennsylvania State University, University Park, PA 16802
}

\begin{abstract}
Additional index words. cuttings, cycloheximide, rooting
Abstract. Adventitious root formation (rooting) in 'Berken' mungbean [Vigna radiata (L.) Rwiclz.] cuttings is stimulated by indole-3-acetic acid (IAA). To understand the molecular events that occur during IAA-induced adventitious root initiation, a $\lambda$ gt 11 cDNA library was made from mungbean hypocotyls treated with $500 \mu \mathrm{M}$ IAA for 3 hours and differentially screened. Two cDNAs MII-3 and MII-4 were isolated. Southern analysis revealed that both cDNAs are encoded by different genes. Expression studies showed different patterns for both genes. Both MII-3 and MII-4 were highly expressed in IAA treated hypocotyls, whereas MII-4 was also induced in IAA treated epicotyls. There was no expression of either $M I I-3$ or $M I I-4$ in control or IAA treated leaves. With increasing concentrations of IAA from 100 to $1000 \mu \mathrm{M}$ there was an increase in the average root number per cutting as well as a stimulation in MII-3 and MII-4. Both MII-3 and MII-4 showed a stimulation in expression 4 hours following treatment with $500 \mu \mathrm{M}$ IAA reaching a maximum from 4 to 8 hours followed by a decline thereafter. Basal expression of MII-3 was evident between 2 and 8 hours, whereas, a high degree of basal expression was found with MII-4 from 1 to 8 hours followed by a sharp decline. Cycloheximide $(50 \mu \mathrm{M})$ dramatically reduced rooting and $M I I-3$ expression, whereas $M I I-4$ was only slightly affected.
\end{abstract}

Adventitious roots in stems and leaves originate in the phloem parenchyma and are therefore, not associated with primary or secondary roots (Lovell and White, 1986). Consequently, stem cuttings, under appropriate conditions, produce adventitious roots resulting in a new root system and a complete plant. Adventitious roots may arise spontaneously or be induced by environmental factors and chemicals (Barlow, 1986). The study of adventitious root formation is important for understanding and controlling root development, and vegetative propagation. Most research on adventitious rooting has focused on the physiological and biochemical events involved in root initiation and development. It has been shown that nucleic acid and protein synthesis are required during rooting (Blazich and Heuser, 1981; Haissig, 1986). Environmental factors, such as light, $\mathrm{CO}_{2}, \mathrm{O}_{2}, \mathrm{pH}$, water, temperature, and nutrients also influence rooting (Andersen, 1986; Davis et al., 1988). The effects of plant hormones on rooting were examined extensively in many plant species (Davis et al., 1988; Jarvis, 1986). It is now generally accepted that auxins play a central role in the initiation and development of adventitious roots. Both natural and synthetic auxins promote rooting, while cytokinins are generally inhibitory (Blakesley et al., 1991). Although past studies have dealt with physiological and biochemical changes during adventitious root formation, information on the molecular mechanism associated with it is limited (Haissig et al., 1992).

Auxin-induced gene expression in intact tissues and cultured cells has been studied for nearly a decade (Guilfoyle, 1986; Key, 1989; Theologis, 1986). Although many auxin-induced or repressed genes have been isolated and characterized in different

Received for publication 26 June 1995. Accepted for publication 12 Oct. 1995. Contribution no. 295, Dept. of Horticulture, The Pennsylvania State Univ. Special thanks to Carl Schlagnhaufer for technical assistance and Jeannette Arteca for assistance preparing the manuscript. The nucleotide sequence data reported in this paper will appear in the EMBL, GenBank and DDBJ Nucleotide Sequence Databases under the accession numbers U20808 (MII-3) and U20809 (MII-4). The cost of publishing this paper was defrayed in part by the payment of page charges. Under postal regulations, this paper therefore must be hereby marked advertisement solely to indicate this fact.

'To whom reprint requests should be addressed. plants and different responses such as: cell division (van der Zaal et al., 1987; Takahashi et al., 1989), cell elongation (Ainley et al., 1988; Conner et al., 1990; Hagen et al., 1984; McClure and Guilfoyle, 1987; Theologis et al., 1985; Yamamoto et al., 1992a and b), fruit ripening (Reddy et al., 1990; Reddy and Poovaiah, 1990), induction of ACC synthase genes (Botella et al., 1992; Kim et al., 1992; Nakagawa et al., 1991), and lateral root initiation (Taylor and Scheuring, 1994), there are presently no reports on the isolation of auxin-responsive genes during adventitious rooting.

To begin the investigation on the molecular control of adventitious rooting, an understanding of the transcriptional events during the initiation of root primordia is needed. This requires the identification of genes whose transcription is necessary under optimal rooting conditions. The mungbean adventitious rooting system is highly responsive to auxins and has been used as a model system for physiological and biochemical studies (Blazich and Heuser, 1979b). The major objective of this study was to identify and characterize genes associated with adventitious rooting in mungbean.

\section{Materials and Methods}

Plant materials. Vigna radiata, mungbean seeds were surfacesterilized in $10 \%(\mathrm{v} / \mathrm{v})$ clorox for $10 \mathrm{~min}$, rinsed in distilled water and aerated for $24 \mathrm{~h}$ in tap water before sowing $1 \mathrm{~cm}$ deep in styrofoam trays containing perlite. The seeds were then grown under continuous cool white fluorescent lights with an irradiance of about $35 \mu \mathrm{mol} \cdot \mathrm{s}^{-1} \cdot \mathrm{m}^{-2}$ at $25 \mathrm{C}$ for 7 days. Seedlings were watered with tap water every other day and on alternate days with a salt solution consisting of $\mathrm{Ca}\left(\mathrm{NO}_{3}\right)_{2} \cdot 4 \mathrm{H}_{2} \mathrm{O}(85 \mathrm{~mm})$ and $\mathrm{H}_{3} \mathrm{BO}_{3}(1.6$ $\mathrm{mm})$. Uniform cuttings from 7-day-old seedlings were produced by removing a portion of the hypocotyl and attached roots $3-\mathrm{cm}$ below the cotyledonary node (Blazich and Heuser, 1979b). Each cutting consisted of a 3-cm hypocotyl, epicotyl, two primary leaves, and an unexpanded trifoliate bud.

Plant treatment and rooting assay. The cuttings were initially placed in distilled water. Ten cuttings were then selected at random and placed in a $19 \times 65-\mathrm{mm}$ shell vial containing $1 \mathrm{ml}$ of treatment solution that contained various chemicals as indicated 
in each experiment. The vials were arranged at random in a growth room under the same temperature and light conditions described for seedling growth. The treatment solution was absorbed within $3 \mathrm{~h}$, after which a sufficient amount of distilled water was added to bring the level of liquid in the vial to the cotyledonary nodes of the cuttings. Additional distilled water was added every $24 \mathrm{~h}$ to maintain that level for the duration of the experiment. After a 120-h incubation period, unless otherwise indicated, the number of roots per cutting was recorded and the mean from 30 cuttings for each treatment taken. Partially elongated roots appearing as bumps below the hypocotyl epidermis and elongated roots above the surface were included in the root counts. Hypocotyls, epicotyls, and primary leaves used for expression studies were harvested from 7-day-old mungbean cuttings treated with $500 \mu \mathrm{M}$ IAA in $5 \mathrm{~mm}$ potassium phophate buffer, pH 6.2, or buffer alone for $3 \mathrm{~h}$. Sections $3 \mathrm{~cm}$ long from primary roots taken from 7 -day-old mungbean seedlings were treated in the same manner as the other plant parts. Treatments involving foliar applications to the primary leaves was accomplished by spraying them to drip with the same solutions previously mentioned with the addition of a drop of Tween 20 . Leaves were harvested $3 \mathrm{~h}$ following treatment.

Construction of cDNA library. Total RNA was extracted according to Chirgwin et al. (1979). Briefly, $12.5 \mathrm{~g}$ of hypocotyls treated with $500 \mu \mathrm{M}$ IAA for $3 \mathrm{~h}$ were pulverized to a fine powder and extracted in $25 \mathrm{ml}$ of extraction buffer ( 25 mm sodium citrate buffer, $\mathrm{pH} 7.0$ containing $4 \mathrm{~m}$ guanidine thiocyanate, $0.5 \%$ sodium sarcosine, $1.56 \mathrm{M} \mathrm{CsCl}, 50 \mathrm{~mm}$ EDTA, and $100 \mathrm{~mm} \beta$ mercaptoethanol). The clarified supernatant was layered onto a $5.7 \mathrm{~m}$ cesium chloride cushion and spun for $16 \mathrm{~h}$ at $37000 \mathrm{rpm}$. The RNA pellet was resuspended in $10 \mathrm{~mm}$ Tris- $\mathrm{HCl}, 5 \mathrm{~mm}$ EDTA ( $\mathrm{pH}$ 8 ), and ethanol precipitated. The pellet was washed with $70 \%$ ethanol and vacuum dried. Poly $(\mathrm{A})^{+}$RNA was purified by oligo dT cellulose according to Sambrook et al. (1989).

Double stranded cDNA was prepared using Amersham's cDNA synthesis system plus kit (Amersham; Arlington Heights, Ill.). A $0.8 \%$ agarose gel was run, dried, and autoradiographed to evaluate the size and quality of the cDNA. Amersham's cDNA cloning system $\lambda$ gt1 1 kit was used for preparation of the library. Recombinant phage DNA was packaged and $E$. coli strain Y1090 was infected.

Differential screening of cDNA library and subcloning. Differential screening was performed using single-stranded cDNA probes synthesized from poly $(\mathrm{A})^{+} \mathrm{RNA}$ isolated from hypocotyls treated for $3 \mathrm{~h}$ with $500 \mu \mathrm{M}$ IAA in $5 \mathrm{~mm}$ potassium phosphate buffer, $\mathrm{pH}$ 6.2 or controls treated with buffer minus IAA. The $\left[{ }^{32} \mathrm{P}\right] \mathrm{dCTP}-$ labeled single stranded cDNA probes were synthesized using random primers as described by Sambrook et al. (1989). About 2000-2500 phage were plated per $15 \times 100 \mathrm{~mm}$ petri plate and 10000 phage were screened. Duplicate nylon membranes (Hybond$\mathrm{N}^{+}$, Amersham) were lifted from each plate and treated according to standard methods (Sambrook et al., 1989). Membranes were dried for $2 \mathrm{~h}$ at $80 \mathrm{C}$ under vacuum. Prehybridization was carried out at $62 \mathrm{C}$ for $4 \mathrm{~h}$ in a solution containing $6 \times \mathrm{SSC}, 0.5 \% \mathrm{SDS}, 5 \times$ Denhardt's reagent, and $100 \mu \mathrm{g} \cdot \mathrm{ml}^{-1}$ denatured salmon sperm DNA. The membranes were then hybridized for $24 \mathrm{~h}$ with the cDNA probes $\left(5 \times 10^{5} \mathrm{cpm} / \mathrm{ml}\right)$ in the same solution and at the same temperature used for prehybridization. Membranes were first washed with $2 \times$ SSC plus $0.1 \%$ SDS for $30 \mathrm{~min}$ at room temperature, then 2 times with $0.2 \times$ SSC plus $0.1 \%$ SDS at $62 \mathrm{C}$ for $30 \mathrm{~min}$ each. The dried membranes were autoradiographed for $24 \mathrm{~h}$ with one intensifying screen at $-80 \mathrm{C}$. Individual positive plaques, which hybridized preferentially with the $\mathrm{IAA}^{+}$probes, but not with the IAA ${ }^{-}$probes were isolated and subject to two additional rounds of plating and hybridization (Sambrook et al., 1989).
The insert cDNA from the positive plaques was excised with $E c o$ $\mathrm{RI}$ and ligated into pBluescript $\left(\mathrm{SK}^{+}\right)$(Stratagene, La Jolla, Calif.) The ligation mixtures were used to transform E. coli $\mathrm{DH} 5 \alpha$. Transformants were selected on LB plates containing ampicillin (50 $\left.\mathrm{mg} \cdot \mathrm{ml}^{-1}\right)$ and X-gal $\left(0.33 \mathrm{mg} \cdot \mathrm{ml}^{-1}\right)$. Plasmid DNA was isolated using the alkaline lysis method (Sambrook et al., 1989).

DNA sequence analysis. DNA sequences were determined by the dideoxynucleotide chain-termination method (Sanger et al., 1977) using Sequenase version 2.0 with universal and reverse M13 sequencing primers (USB, Cleveland, Ohio). DNA sequence analysis was facilitated by the use of the Intelligenetics molecular biology software. The percentage homology was determined using FASTDB program in the Intelligenetics software.

Northern blot analysis. Total RNA was extracted from roots, hypocotyls, epicotyls, and leaves of 7-day-old seedlings or cuttings treated with various chemicals frozen in liquid nitrogen and stored at $-80 \mathrm{C}$ until used as previously described by Chirgwin et al. (1979). Total RNA $(10 \mu \mathrm{g})$ was fractionated on a $1 \%$ agarose gel containing $2.2 \mathrm{M}$ formaldehyde. After electrophoresis, the RNA was transferred to a nylon membrane by capillary transfer according to standard procedures (Sambrook et al., 1989). Probes were labeled with $\left[{ }^{32} \mathrm{P}\right] \mathrm{dCTP}$ by the random-primer method with Amersham's Multiprime DNA labeling system. The membranes were first prehybridized for $4 \mathrm{~h}$ in a solution containing $50 \%$ formamide, $6 \times$ SSC, $5 \times$ Denhardt's reagent, $0.5 \%$ SDS, and $200 \mu \mathrm{g} \cdot \mathrm{ml}^{-1}$ denatured salmon sperm DNA at $42 \mathrm{C}$, then hybridized in the same solution with cDNA probes $\left(5 \times 10^{6} \mathrm{cpm} / \mathrm{ml}\right)$ overnight at the same temperature. Membranes were washed 2 times for 15 min with $2 \times$ SSC plus $0.1 \%$ SDS at room temperature, twice for 15 min with $2 \times$ SSC plus $0.1 \%$ SDS at $62 \mathrm{C}$, and twice for 15 min with $0.2 \times$ SSC plus $0.1 \%$ SDS at 62C. Membranes were exposed to X-ray film with two intensifying screens at $-80 \mathrm{C}$ overnight. Blots were stripped and rehybridized with a pea ribosomal gene (Jorgenson et al., 1982), which was expressed constitutively and did not respond to IAA to ensure that equal amounts of RNA were loaded in each lane.

Genomic southern analysis. Genomic DNA was extracted from leaves of 7-day-old mungbean seedlings by the phenol/ chloroform method and purified by $\mathrm{CsCl}$ centrifugation (Sambrook et al., 1989). Leaves (10 g) were frozen in liquid nitrogen, ground to a fine powder, and then extracted in $50 \mathrm{ml}$ of buffer containing $100 \mathrm{~mm}$ Tris-HCl, 50 mм EDTA (pH 8.0), $250 \mathrm{~mm} \mathrm{NaCl}, 1 \%$ Sarkosyl and $2 \% \beta$-mercaptoethanol. The mixture was then centrifuged for $15 \mathrm{~min}$ at $16000 \times g$, the supernatant extracted twice with phenol : chloroform : isoamyl alcohol (25:24:1), and the nucleic acids recovered by ethanol precipitation. The pellet was resuspended in $10 \mathrm{ml}$ of TE buffer $\left(\mathrm{pH} \mathrm{8.0)}\right.$ and $\mathrm{CsCl}\left(1 \mathrm{~g} \cdot \mathrm{ml}^{-1}\right)$ was added before ultracentrifugation at $300000 \times g$ for $20 \mathrm{~h}$. The DNA band was collected and ethanol precipitated. The DNA pellet was resuspended in $500 \mu \mathrm{l}$ of TE buffer. About $10 \mu \mathrm{g}$ of DNA was digested with restriction endonucleases (Eco RI, Bam HI, Hind III), size fractionated on a $0.6 \%$ agarose gel, and transferred to nylon membranes by capillary transfer (Sambrook et al., 1989). Prehybridization and hybridization conditions were the same as described for the northern analysis. The washing steps were two times for 10 min with $2 \times$ SSC plus $0.1 \%$ SDS at room temperature, 1 time for $30 \mathrm{~min}$ with $0.1 \times \mathrm{SSC}$ plus $0.1 \% \mathrm{SDS}$ at room temperature, and 1 time for $30 \mathrm{~min}$ with $0.1 \times \mathrm{SSC}$ plus $0.1 \%$ SDS at 65C. Air dried membranes were exposed to X-ray film with two intensifying screens at $-80 \mathrm{C}$ overnight.

\section{Results and Discussion}

Sequence analysis. The complete nucleotide and deduced amino 
acid sequences for MII-3 and MII-4 are shown in Fig. 1. MII-3 is $1261 \mathrm{bp}$ long and contains an open reading frame of $954 \mathrm{bp}$ that encodes a 317 amino acid polypeptide. It has a 96-bp leader sequence and a 212-bp trailing region that contains two potential polyadenylation signals. MII-4 is $1148 \mathrm{bp}$ long and contains an open reading frame of $693 \mathrm{bp}$ that encodes a 230 amino acid polypeptide. It has a 455-bp trailing region that contains three potential polyadenylation signals. A comparison of nucleotide and predicted amino acid sequences for MII-3 and MII-4 with other reported genes was performed using the BLAST programs (Altschul et al., 1990). MII-3 showed no significant similarities to other genes or proteins in the databases. However, similarities between the deduced amino acid sequence of $M I I-4$ and a heat shock protein from soybean (M20363) (Czarnecka et al., 1988), an auxininduced protein from soybean (J03197) (Hagen et al., 1988) and an auxin-induced protein from tobacco (X56264) (van der Zaal et al.,

A

\section{MII-3}

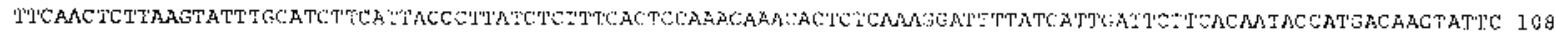
$M \quad I ' \quad S \quad I$

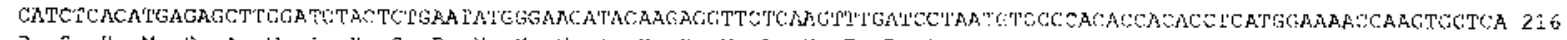

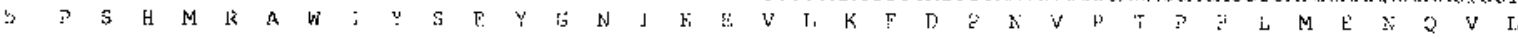

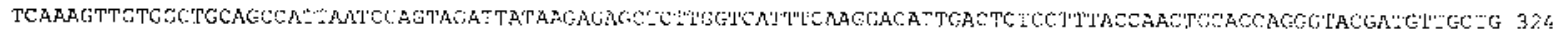

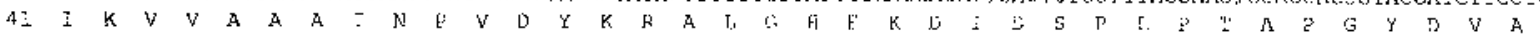

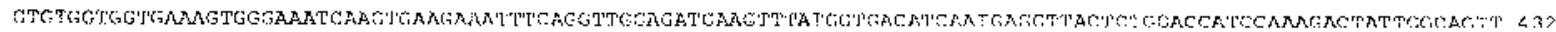

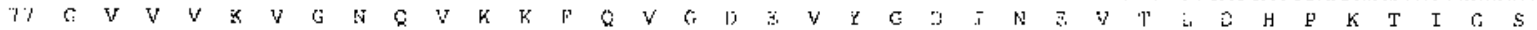

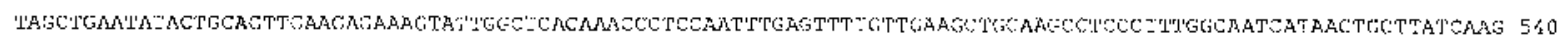

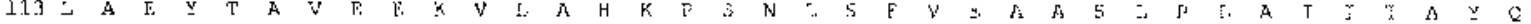

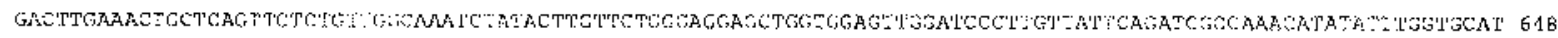

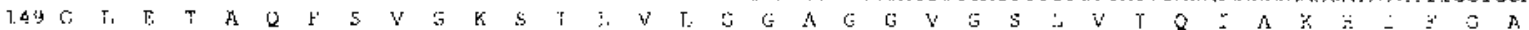

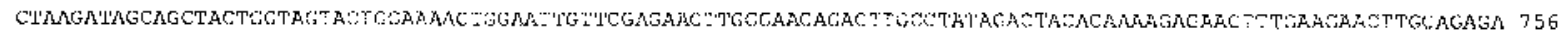

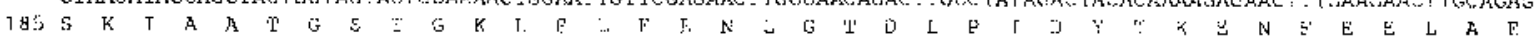

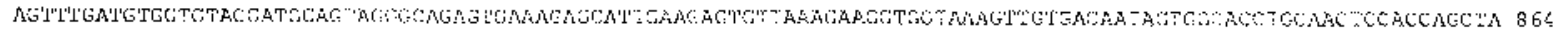

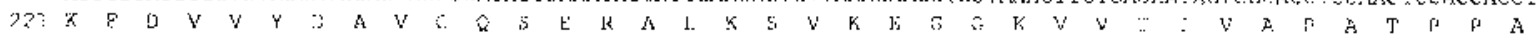

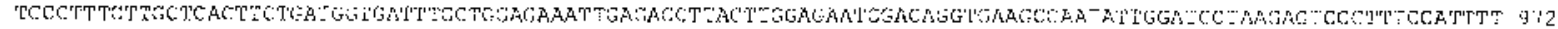

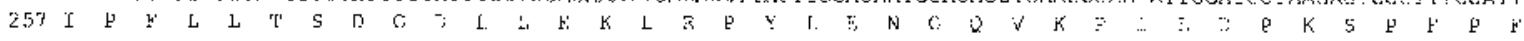

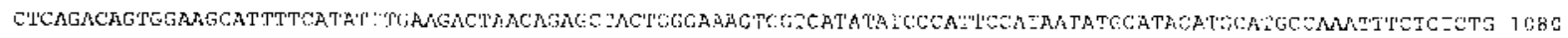

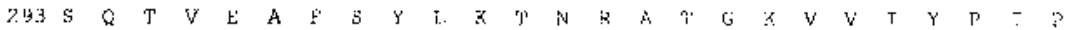

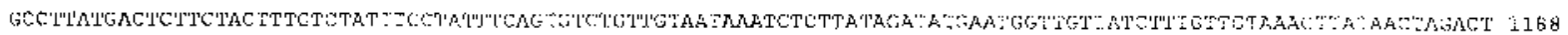

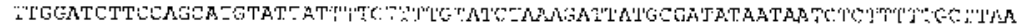

B

\section{MII-4}

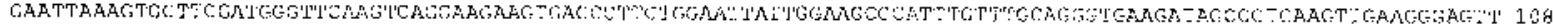

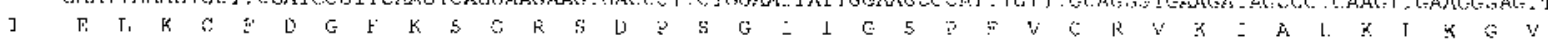

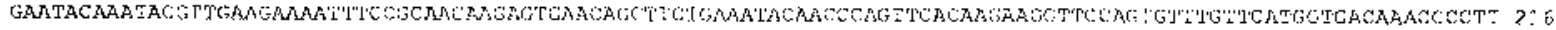

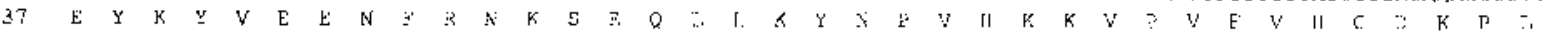

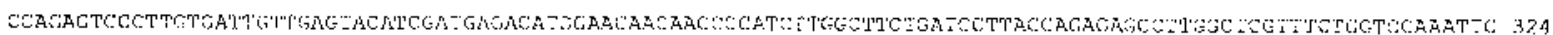

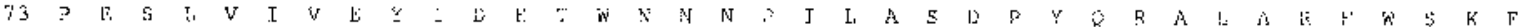

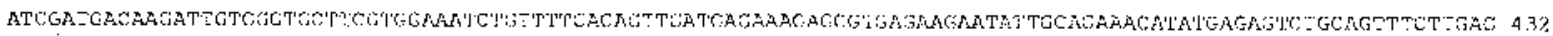

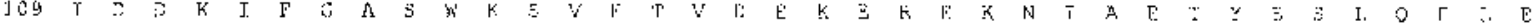

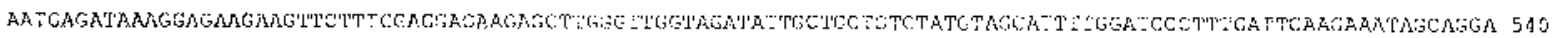

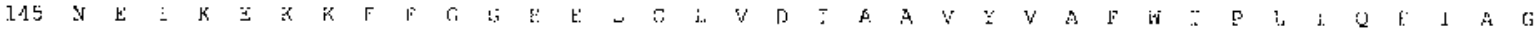

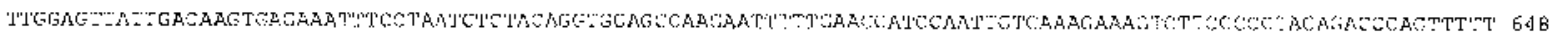

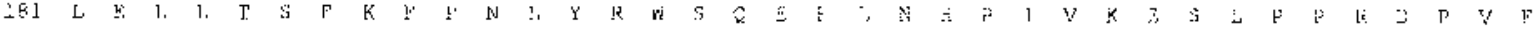

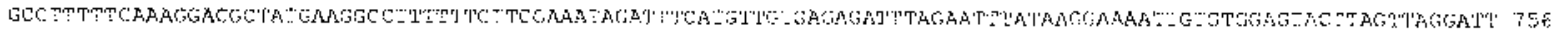

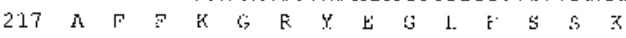

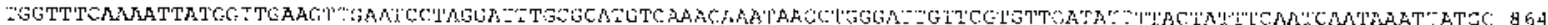

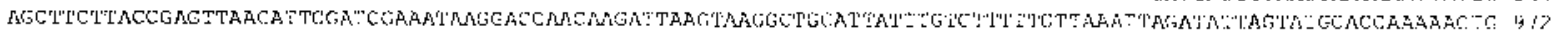

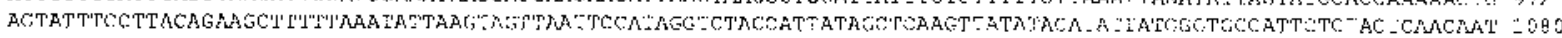

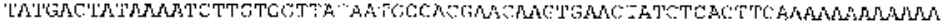

Fig. 1. The complete nucleotide and deduced amino acid sequences of auxin-induced mungbean cDNA clones MII-3 (A) and MII-4 (B). 


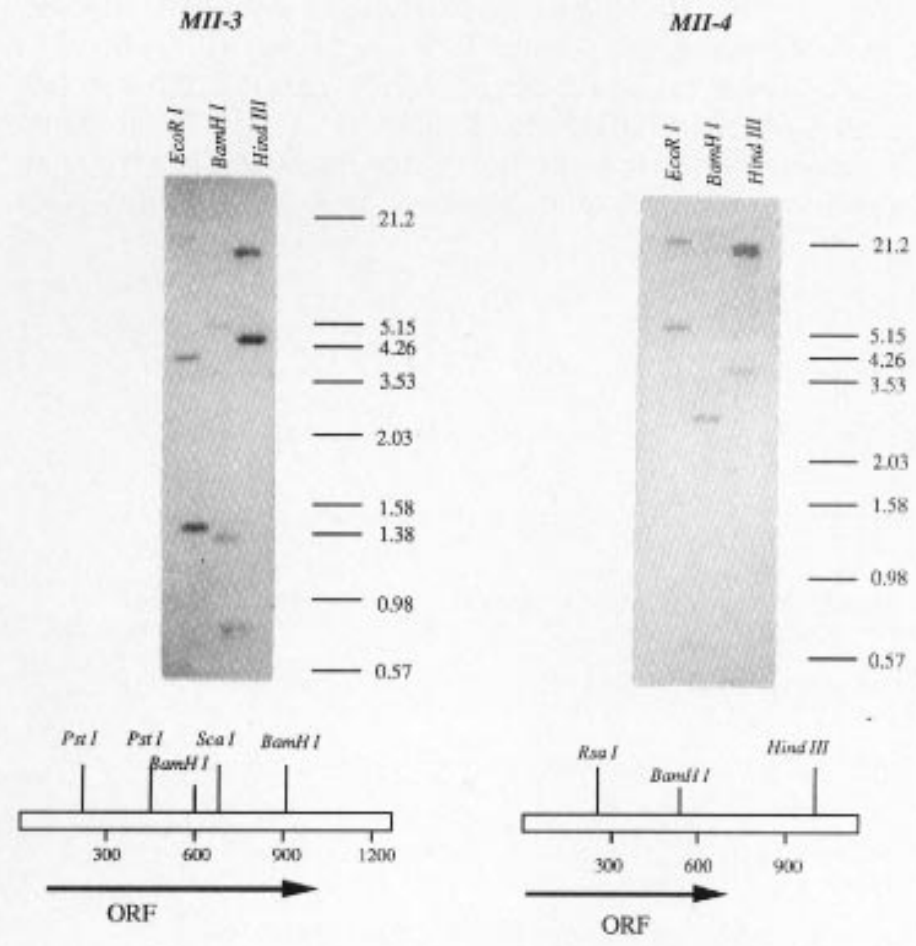

Fig. 2. Southern blot analysis of mungbean genomic DNA digested with Eco RI, Bam HI, and Hind III and probed with $\left[{ }^{32} \mathrm{P}\right] \mathrm{dCTP}-$ labeled MII-3 or MII-4 cDNA. A partial restriction map for $M I I-3$ or $M I I-4$ cDNA is located below its respective blot.

1991) were $80 \%, 79 \%$, and $52 \%$, respectively. Similarity between MII-4 with other auxin-induced genes including: Aux (Ainley et al., 1988, Conner et al., 1990), SAUR (McClure and Guilfoyle, 1987), par (Takahashi et al., 1989), PS-IAA4/5 and PS-IAA6 (Oeller et al., 1993; Theologis et al., 1985), ARG (Yamamoto et al., 1992a, b), ISAR (Reddy et al., 1990), and RSI (Taylor and Sheuring, 1994) was <35\%.

Genomic southern analysis. When digested mungbean genomic DNA was probed with $M I I-3$, there were two bands in the Eco RIlane, two bands in the Hind III lane, and three bands in the Bam HI lane (Fig. 2A). In the MII-3 cDNA there are no Eco RI or Hind III sites and two Bam HI sites. The additional bands may have been due to sites found in the introns of this gene or due to cross hybridization with closely related genes. However, the possibility exists that additional copies of this gene may be present in the mungbean genome. When digested DNA was probed with $M I I-4$ there were two bands found in the Eco RI lane, while in the Hind III and Bam HI lanes three bands were found (Fig. 2B). In the MII-4 cDNA there is one Bam HI site, one Hind III site, and no Eco RI site present. The two bands found in the Bam HI lane are in agreement with cDNA sequence information, however, the additional bands found in the Eco RI lane may have been due to sites found in introns of this gene or due to cross hybridization with closely related genes. But, the possibility also exists that additional copies of this gene may be present.

Expression of MII-3 and MII-4 in different plant parts. To evaluate if MII-3 and MII-4 expression was tissue specific, total RNA from roots, hypocotyls, epicotyls, and leaves from 7-day-old mungbean seedlings with or without IAA treatment were probed. Northern blot analysis revealed that without auxin treatment MII-3 was not present in hypocotyls, roots, epicotyls, and leaves (Fig. 3). Low levels of

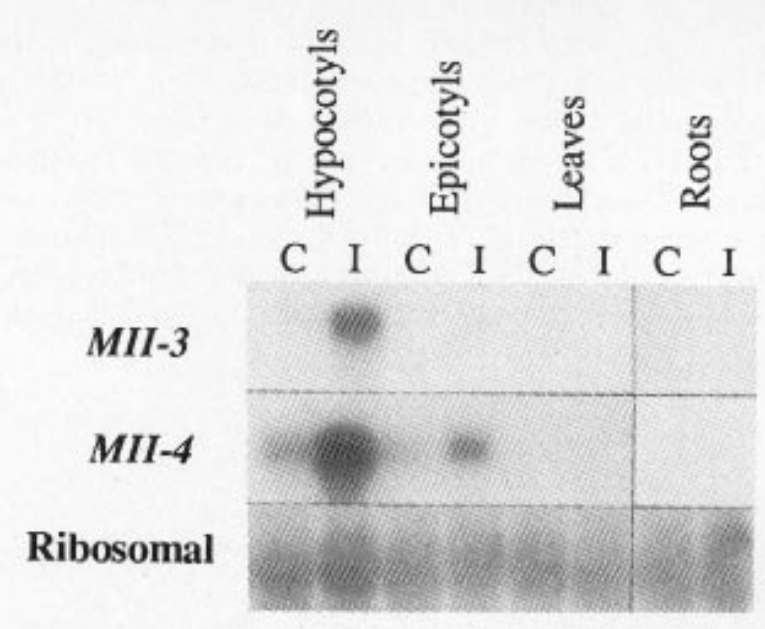

Fig. 3. Abundance of $M I I-3$ and $M I I-4$ expression in various parts of mungbean cuttings with and without IAA treatment. Cuttings made from 7-day-old mung bean seedlings were treated with $500 \mu \mathrm{M}$ IAA (I) in $5 \mathrm{~mm}$ potassium phosphate buffer, $\mathrm{pH}$ 6.2, or buffer alone (C) for $3 \mathrm{~h}$. Total RNA (10 $\mu \mathrm{g})$ from hypocotyls, epicotyls, leaves, and roots was probed with [ ${ }^{32} \mathrm{P}$ ]dCTP-labeled $M I I-3$ or $M I I-4$ cDNA and a pea ribosomal gene.

MII-4 were present in hypocotyls and epicotyls but not detectable in roots or leaves. Three hours following treatment with $500 \mu \mathrm{MIAA}$, MII-3, and MII-4 were dramatically stimulated in mungbean hypocotyls. IAA had no effect on MII-3 levels in epicotyls, leaves, and roots, however, slightly promoted MII-4 levels in epicotyls (Fig. 3).

Adventitious roots arise from the hypocotyl region of the mungbean cuttings. Without exogenous IAA treatment, roots only come from the very bottom of the hypocotyl. With IAA treatment roots develop in four longitudinal rows along the whole hypocotyl (Blazich and Heuser, 1979a). We also found that the epicotyl region formed adventitious roots especially when the hypocotyl was excised from the cutting or was damaged (data not shown). Thus, the major expression of MII-3 and MII-4 in the hypocotyl and the low levels of MII-4 in the epicotyl of mungbean cuttings

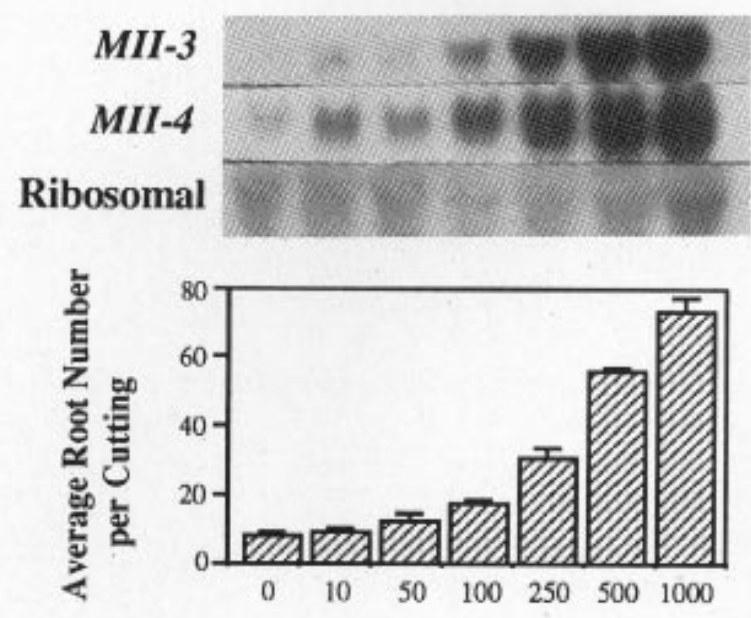

IAA Concentration $(\mu \mathrm{M})$

Fig. 4. Effects of IAA on MII-3 and MII-4 expression and adventitious rooting in hypocotyls from mungbean cuttings. Total RNA $(10 \mu \mathrm{g})$ isolated from hypocotyls of cuttings treated with different concentrations of IAA for $3 \mathrm{~h}$ (control, $5 \mathrm{~mm}$ potassium phosphate buffer, $\mathrm{pH} 6.2$, indicated as $0 \mu \mathrm{M}$ ) was probed with $\left.{ }^{32} \mathrm{P}\right] \mathrm{dCTP}-$ labeled $M I I-3$ or $M I I-4$ cDNA and a pea ribosomal gene. The bottom panel shows adventitious root formation in mungbean cuttings in response to different concentrations of IAA. Bars indicate standard error of the mean 


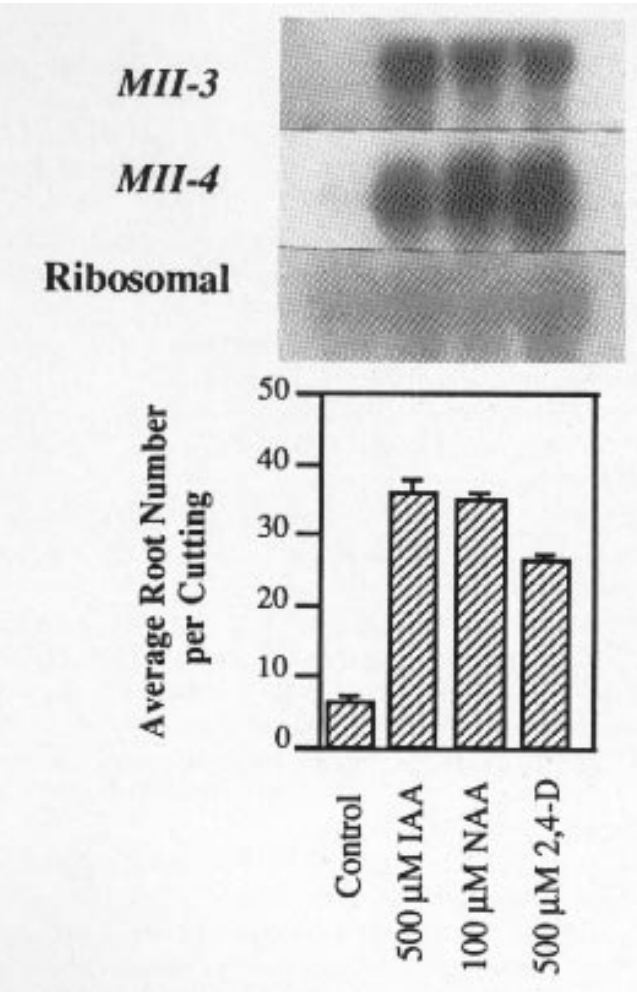

Fig. 5. Effect of IAA $(500 \mu \mathrm{M})$, NAA $(100 \mu \mathrm{M})$ and $2,4-\mathrm{D}(500 \mu \mathrm{M})$ on the expression of MII-3 and MII-4 in mungbean cuttings $3 \mathrm{~h}$ following treatment initiation. Total RNA $(10 \mu \mathrm{g})$ isolated from hypocotyls in each treatment was probed with $\left[{ }^{32} \mathrm{P}\right] \mathrm{dCTP}-$ labeled MII-3 and MII-4 cDNA and a pea ribosomal gene. The panel on the bottom shows adventitious root formation in mungbean cuttings in response to IAA, NAA, and 2,4-D as indicated. Bars indicate standard error of the mean.

\section{Time(h)}

\section{$\begin{array}{lllllll}1 & 2 & 4 & 6 & 8 & 10 & 12\end{array}$}

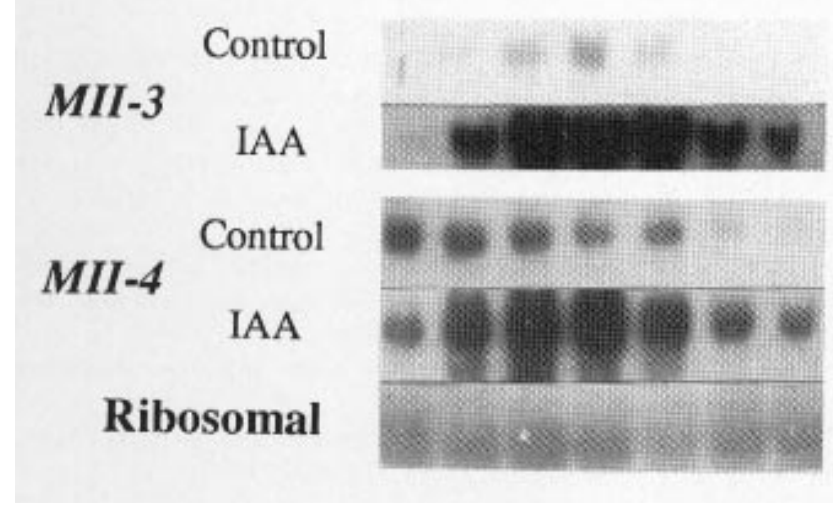

Fig. 6. MII-3 and MII-4 expression in mungbean hypocotyls treated with $500 \mu \mathrm{M}$ IAA or $5 \mathrm{~mm}$ potassium phosphate buffer, $\mathrm{pH} 6.2$ (control) $3 \mathrm{~h}$ following treatment initiation. Total RNA $(10 \mu \mathrm{g})$ isolated from hypocotyls at various time intervals as indicated was probed with $\left[{ }^{32} \mathrm{P}\right] \mathrm{dCTP}-$ labeled $M I I-3$ and $M I I-4 \mathrm{cDNA}$ and a pea ribosomal gene.

after IAA treatment is correlated with rooting potential.

There was no induction of MII-3 or MII-4 in leaf tissue $3 \mathrm{~h}$ following IAA application to the base of the cutting (Fig. 3). To evaluate if this was caused by an IAA concentration gradient formed in the cutting, the same concentration of IAA was sprayed directly on the leaves attached to cuttings. To be sure that IAA was taken-up by the leaf, IAA-induced ethylene production was evaluated and shown to increase dramatically in response to foliar applications (data not

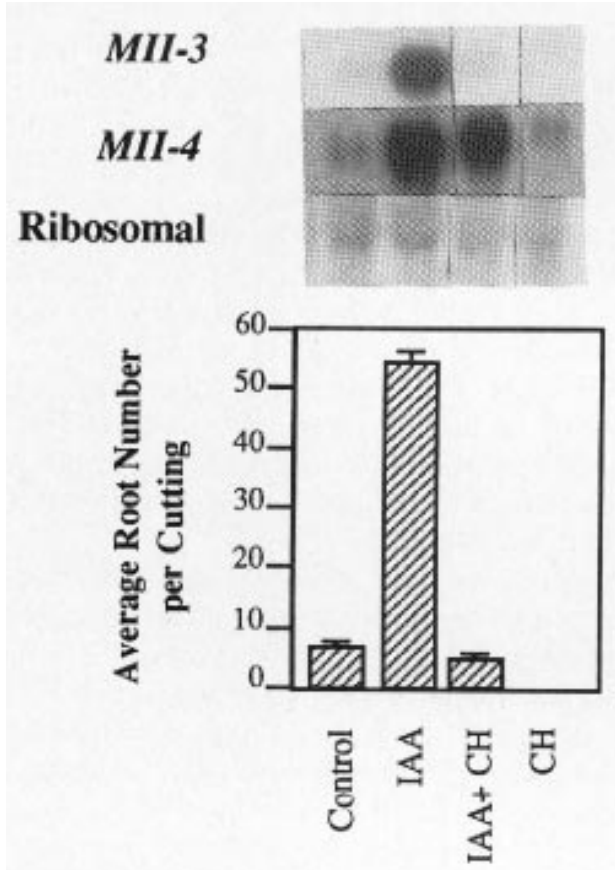

Fig. 7. Effect of $500 \mu \mathrm{M}$ IAA or $50 \mu \mathrm{M}$ cycloheximide $(\mathrm{CH})$ alone and in combination on the expression of MII-3 and MII-4 in mungbean cuttings $3 \mathrm{~h}$ following treatment initiation. Total RNA $(10 \mu \mathrm{g})$ isolated from hypocotyls of cuttings in each treatment were probed with [ $\left.{ }^{32} \mathrm{P}\right] \mathrm{dCTP}$-labeled MII-3 and MII4 cDNA and a pea ribosomal gene. The bottom panel shows adventitious root formation in mungbean cuttings in response to IAA or $\mathrm{CH}$. Bars indicate standard error of the mean.

shown), thereby providing evidence that IAA was taken up by the whleaf. However, foliar application of IAA had no effect on MII-3 and MIII-4 expression $3 \mathrm{~h}$ following treatment (data not shown). Although spe II-3 and MII-4 are auxin-inducible and exhibit strong tissueinviecificity, further investigation is necessary to evaluate if they are volved in the initiation of roots in mungbean.

levi Effects of auxin on MII-3 and MII-4 expression and rooting. Basal theivels of MII-3 and MII-4 were found in mungbean hypocotyls and $M I$ rere was a dose-dependent increase in the expression of MII- 3 and MIIII-4 following the initiation of IAA treatment. Expression of both (Fig II-3 and MII-4 increased as the concentration of IAA increased coilig. 4). The IAA dose-dependent rooting response shown in Fig. 4 hypincides with increases in MII-3 and MII-4 expression in the or I'pocotyls following IAA treatment. NAA $(100 \mu \mathrm{M}), 2,4-\mathrm{D}(500 \mu \mathrm{M})$ cutt IAA $(500 \mu \mathrm{M})$ promote adventitious root formation in mungbean witttings as well as MII-3 and MII-4 expression that corresponded ith the increase in rooting observed (Fig. 5).

3 in Kinetics of MII-3 and MII-4 expression. Over a time course, MII$\checkmark$ in control hypocotyls was detected within $4 \mathrm{~h}$ after initiation of the experiment, reached a maximum at $6 \mathrm{~h}$, and declined thereafter (Fig. 6). Two hours following the initiation of IAA treatment $(500 \mu \mathrm{M})$ MII-3 levels increased, reaching a peak from 4 to $8 \mathrm{~h}$, followed by a decline (Fig. 6). Basal levels of MII-4 in the control remained fairly constant through $8 \mathrm{~h}$ followed by a sharp decline $10 \mathrm{~h}$ after treatment initiation, and by $12 \mathrm{~h}$ was not detected. Two hours following the initiation of IAA $(500 \mu \mathrm{M})$ treatment, there was a dramatic increase in MII- 4 levels, reaching a peak from 4 to $8 \mathrm{~h}$ followed by a decline (Fig. 6). It has been reported that the first cell divisions of the phloem parenchyma leading to adventitious root initiation occur 20-24 h following the initiation of auxin treatment (Blazich and Heuser, 1979a). Tripepi et al. (1983), using ${ }^{3} \mathrm{H}$-uridine and ${ }^{3} \mathrm{H}$-thymidine uptake as indicators of RNA and DNA synthesis, respectively, observed that nuclei in the potential rooting zone cells were labeled 
with ${ }^{3} \mathrm{H}$-uridine (nucleolus) within $2 \mathrm{~h}$ following the initiation of auxin treatment. ${ }^{3} \mathrm{H}$-thymidine was incorporated $14-16 \mathrm{~h}$ later. They suggested that ${ }^{3} \mathrm{H}$-uridine was incorporated into mRNA in the nucleoli and that the initial transcriptional events occurred within 24 $h$ in the rooting zone parenchyma.

In the presence of IAA, cycloheximide dramatically inhibited adventitious rooting and MII-3 expression, while having an observable, but slight inhibition of MII-4 (Fig. 7). Cycloheximide treatment had no observable effect on basal levels of either MII-3 or MII-4 (Fig. 7). The inhibitory effect of cycloheximide on the expression of the auxin-induced MII-3 and MII-4 is contrary to its effect on other reported auxin-induced genes where it has been shown to dramatically promote expression (Franco et al., 1990; Theologis et al., 1985).

In summary, we have identified and characterized 2 cDNA clones corresponding to auxin-induced mRNAs by differentially screening a $\lambda$ gt 11 cDNA mungbean library. The data presented here show that auxin induced the expression of MII-3 and MII-4 in the hypocotyls of mungbean cuttings, which corresponded with an increase in adventitious root initiation. Although there was a correlation of inducibility of $M I I-3$ and $M I I-4$ with adventitious rooting, further investigation is necessary to evaluate whether or not they are directly responsible for the initiation of roots in mungbean.

\section{Literature Cited}

Altschul, S.F., W. Gish, W. Miller, E.W. Myers, and D.J. Lipman. 1990. Basic local alignment search tool. J. Mol. Biol. 215:403-410.

Andersen, A.S. 1986. Environmental influences on adventitious rooting in cuttings of non-woody species, p. 223-253. In: M.B. Jackson (ed.). New root formation in plant and cuttings. Martinus Nijhoff, Dordrecht.

Ainley, W.M., J.C. Walker, R.T. Nagao, and J.L. Key. 1988. Sequence and characterization of two auxin-regulated genes from soybean. J. Biol. Chem. 263:1065810666.

Barlow, P.W. 1986. Adventitious roots of whole plants: Their forms, functions, and evolution, p. 67-110. In: M.B. Jackson (ed.). New root formation in plant and cuttings. Martinus Nijhoff, Dordrecht.

Blakesley, D., G.D. Weston, and J.F. Hall. 1991. The role of endogenous auxin in root initiation. Plant Growth Regulat. 10:341-353.

Blazich, F.A. and C.W. Heuser. 1979a. A histological study of adventitious root initiation in mungbean cuttings. J. Amer. Soc. Hort. Sci. 104:63-67.

Blazich, F.A. and C.W. Heuser. 1979b. The mung bean rooting bioassay: A reexamination. J. Amer. Soc. Hort. Sci. 104:117-120.

Blazich, F.A. and C.W. Heuser. 1981. Effects of selected putative inhibitors of ribonucleic acid or protein synthesis on adventitious root formation in mungbean cuttings. J. Amer. Soc. Hort. Sci. 106:8-11.

Botella, J.R., J.M. Arteca, C.D. Schlagnhaufer, R.N. Arteca, and A.T. Phillips. 1992. Identification and characterization of a full-length cDNA encoding for an auxininduced 1-aminocyclopropane-1-carboxylate synthase from etiolated mung bean hypocotyl segments and expression of its mRNA in response to indole-3-acetic acid. Plant Mol. Biol. 20:425-436.

Chirgwin, J.M., A.E. Przbyla, R.J. MacDonald, and W. J. Rutter. 1979. Isolation of biologically active ribonucleic acid from sources enriched with ribonucleases. Biochemistry 18: 5294.

Conner, T.W., V.H. Goekjian, P.R. Lafayette, and J.L. Key. 1990. Structure and expression of two auxin-induced genes from Arabidopsis. Plant Mol. Biol. 15:153157.

Czarnecka, E., R.T. Nagao, J.L. Key, and W.B. Gurley. 1988. Characterization of Gmhsp26, a stress gene encoding a divergent heat shock protein of soybean: Heavymetal-induced inhibition of intron processing. Mol. Cell Biol. 8:1113-1122.

Davis, T.D., B.E. Haissig, and N. Sankhla N. 1988. Adventitious root formation in cuttings. Advances in Plant Science Series. vol. 2. Dioscorides Press, Portland, Ore.

Franco, A.R., M.A. Gee, and T.J. Guilfolye. 1990. Induction and superinduction of auxin-responsive mRNAs with auxin and protein synthesis inhibitors. J. Biol. Chem. 265:15845-15849.

Guilfoyle, T.J. 1986. Auxin regulated gene expression in higher plants. CRC Crit.
Rev. Plant Sci. 4: 247-277.

Hagen, G., N. Uhrhammer, and T.J. Guilfoyle. 1988. Regulation of expression of an auxin-induced soybean sequence by cadminum. J. Biol. Chem. 263:6442-6446.

Hagen, G., A. Kleinschmidt, and T.J. Guilfoyle. 1984. Auxin-regulated gene expression in intact soybean hypocotyl and excised hypocotyl sections. Planta 62:147153.

Haissig, B.E. 1986. Metabolic processes in adventitious rooting of cuttings, p. 141190. In: M.B. Jackson (ed.). New root formation in plant and cuttings. Martinus Nijhoff, Dordrecht.

Haissig, B.E., T.D. Davis, and D. E. Riemenschneider. 1992. Researching the controls of adventitious rooting. Physiol. Plant. 84:310-317.

Jarvis, B.C. 1986. Endogenous control of adventitious rooting in non-woody cuttings, p. 191-222. In: M.B. Jackson (ed.). New root formation in plant and cuttings. Martinus Nijhoff, Dordrecht.

Jorgenson, R.A., R.E. Cuellar, and W.F. Thompson. 1982. Modes and tempos in the evolution of nuclear encoded ribosomal RNA genes in legumes. Carnegie Inst. Wash. Yearbook 81:98-101.

Key, J.L. 1989. Modulation of gene expression by auxin. BioEssays 11:52-58.

Kim, W.T., A. Silverstone, W.K. Yip, J.G. Dong, and S.F. Yang. 1992. Induction of 1-aminocyclopropane-1-carboxylate synthase mRNA by auxin in mung bean hypocotyls and cultured apple shoots. Plant Physiol. 98:465-471.

Lovell, V.H. and J. White. 1986. Anatomical changes during adventitious root formation, p. 111-140. In: M.B. Jackson (ed.). New root formation in plant and cuttings. Martinus Nijhoff, Dordrecht.

McClure, B.A. and T.J. Guilfoyle. 1987. Characterization of a class of small auxininducible soybean polyadenylated RNAs. Plant Mol. Biol. 9:611-613.

Nakagawa, N., H. Mori, K. Yamazaki, and H. Imaseki. 1991. Cloning of a complementary DNA for auxin-induced 1-aminocyclopropane-1-carboxylate synthase and differential expression of the gene by auxin and wounding. Plant Cell Physiol. 32:1153-1163.

Oeller, P.W., J.A. Keller, J.E. Parks, J.E. Silbert, and A. Theologis. 1993. Structural characterization of the early indoleacetic acid-inducible genes, $P S-I A A 4 / 5$ and $P S$ IAA6, of pea (Pisum sativum L.). J. Mol. Biol. 233:789-798.

Reddy, A.S.N. and B.W. Poovaiah. 1990. Molecular cloning and sequencing of a cDNA for an auxin-repressed mRNA correlating between fruit growth and repression of the auxin-regulated gene. Plant Mol. Biol. 14:127-136.

Reddy, A.S.N., P.K. Jean, S.K. Mukherjee, and B.W. Poovaiah. 1990. Molecular cloning of cDNAs for auxin-induced mRNAs and developmental expression of auxin-inducible genes. Plant Mol. Biol. 14:643-653.

Sambrook, J., Fritsch, E.F., and T. Maniatis. 1989. Molecular cloning: A laboratory manual. Cold Spring Harbor Press, Cold Spring Harbor, N.Y.

Sanger, F., S. Nicklen, and A.R. Coulson. 1977. DNA sequencing with chainterminating inhibitors. Proc. Natl. Acad. Sci. USA 74:5463-5467.

Takahashi, Y., H. Kuroda, T. Tanaka, Y. Machida, I. Takebe, and T. Nageta. 1989 Isolation of an auxin-regulated gene cDNA expressed during the transition from $\mathrm{G}$ to S phase in tobacco mesophyll protoplasts. Proc. Natl. Acad. Sci. USA 86:92799283.

Taylor, B.H. and C.F. Sheuring. 1994. A molecular marker for lateral root initiation: The RSI-1 gene of tomato (Lycopersicon esculentum Mill) is activated in early lateral root primordia. Mol. Gen. Genet. 243:148-157.

Theologis, A. 1986. Rapid gene regulating by auxin. Annu. Rev. Plant Physiol. 37:407-438

Theologis, A., T.V. Huyhn, and R.W. Davis. 1985. Rapid induction of specific mRNAs by auxin in pea epicotyl tissue. J. Mol. Biol. 183:53-68.

Tripepi, R.R., C.W. Heuser, and J.C. Shannon. 1983. Incorporation of tritiated thymidine and uridine into adventitious-root initial cells of Vigna radiata. J. Amer. Soc. Hort. Sci. 108:469-474.

van derZaal, E.J.,F.N. Droog, C.J. Boot, L.A. Hensgens, J.H. Hoge, R.A. Schilperoort, and K.R. Libbenga. 1991. Promoters of auxin-induced genes from tobacco can lead to auxin-inducible and root-tip specific expression. Plant Mol. Biol. 16:983-998. van der Zaal, E.J., J. Memelink, A.M. Mennes, A. Quint, and K.R. Libbenga. 1987. Auxin-induced mRNA species in tobacco cell culture. Plant Mol. Biol. 10:145157.

Yamamoto, K.T., H. Mori, and H. Imaseki. 1992a. Novel mRNA sequences induced by indole-3-acetic acid in section of elongation of hypocotyls of mung bean (Vigna radiata). Plant Cell Physiol. 33:13-20.

Yamamoto, K.T., H. Mori, and H. Imaseki. 1992b. cDNA cloning of indole-3-acetic acid-regulated gene, Aux 22, and SAUR from mung bean (Vigna radiata) hypocotyl tissue. Plant Cell Physiol. 33:93-9 